\title{
Factors influencing the loss of bacteria in preserved seawater samples
}

\author{
Kjell Gundersen $^{1, *}$, Gunnar Bratbak ${ }^{2}$, Mikal Heldal ${ }^{2}$ \\ ${ }^{1}$ Bermuda Biological Station for Research, 17 Biological Station Lane, Ferry Reach, St George GE 01, Bermuda \\ ${ }^{2}$ Department of Microbiology, University of Bergen, Jahnebakken 5, N-5020 Bergen, Norway
}

\begin{abstract}
Several time course storage experiments with preserved seawater samples were conducted to study the loss of bacterial cells as a function of storage time. The number of bacteria decreased by 24 to $50 \%$ within 7 to $29 \mathrm{~d}$ in samples preserved with $2.5 \%$ glutaraldehyde (final conc.). A comparison between epifluorescence and electron microscope counts showed that the decrease was not due to filtration artefacts. Only 0.4 to $0.6 \%$ of the bacterial cells were found to be attached to the walls of the sample containers after 1 yr of storage. There was no positive correlation between the frequency of virus-infected cells at the start of the storage experiments and the loss of bacteria as a function of storage time. Numbers of bacteria declined by only $5 \%$ the first $9 \mathrm{~d}$ in samples preserved in glutaraldehyde and stored at $-20^{\circ} \mathrm{C}$. By adding phenolmethylsulfonylfluoride (PMSF), a protease inhibitor, prior to the addition of glutaraldehyde, the loss of bacterial cells only 17 to $18 \%$ over a 30 to $35 \mathrm{~d}$ period. Our study shows that protease activity may be a major cause of bacterial loss in glutaraldehyde preserved samples
\end{abstract}

KEY WORDS: Bactena Preservation Glutaraldehyde PMSF

\section{INTRODUCTION}

Bacteria are considered to be the main heterotrophic link between particles and dissolved organic matter, in open ocean and coastal ecosystems (Pomeroy 1974, Azam et al. 1983). Although still widely discussed (Li et al. 1992, Caron et al. 1995, Roman et al. 1995), bacterial biomass has also been suggested to be a major part of the particulate organic carbon pool in open ocean and coastal water communities (Dortch \& Packard 1989, Fuhrman et al. 1989, Cho \& Azam 1990). Therefore, an accurate assessment of bacterial abundance and biomass is important in the study of aquatic biogeochemical cycling of carbon, nitrogen and phosphorus. Direct microscopic counts of bacteria stained with fluorescent dyes (Zimmerman \& Meyer-Reil 1974, Hobbie et al. 1977, Porter \& Feig 1980) has been a standard procedure the last 2 decades for enumerating bacteria in natural water samples. Due to the relative ease of handling and low cost, epifluoresecence microscopy (EFM) is by far the most widely used tech-

·E-mail: kjell@bbsr.edu nique to enumerate bacteria. Bacterial samples preserved with formaldehyde or glutaraldehyde are routinely stored at $4^{\circ} \mathrm{C}$ for weeks, months and sometimes years before counting.

Questions have been raised about the preservation of bacteria in stored samples. In a comparative study of bacterial preservatives, Nishino (1986) found Lugol's iodine to be superior to glutaraldehyde preservation of marine bacteria, but the number of bacteria declined in both treatments as a function of storage time. A loss of 45 and $69 \%$ of the initial bacteria concentration was found in seawater samples preserved with glutaraldehyde after 1 and 6 mo storage at $+4^{\circ} \mathrm{C}$ (Nishino 1986). Spinrad et al. (1989) noted a loss of bacteria in formaldehyde preserved samples stored for 2 mo and applied a logarithmic function to correct the bacterial cell concentration. Indeed, a loss of bacteria has been observed with most commonly used poisons or preservatives, such as Lugol's solution (Nishino 1986), formaldehyde (Spinrad et al. 1989) and glutaraldehyde (Nishino 1986, Turley \& Hughes 1992).

There are several potential processes that may cause a loss of bacteria in preserved samples. These include: 
(1) attachment of cells to the bottle surface and other surfaces (aggregates) in the sample (Turley \& Hughes 1992); (2) cell shrinkage, which may cause an increased loss by filtration and preparation of the sample; (3) virus-infected bacteria in the lytic cycle may lyse and disintegrate cells in the preserved sample; (4) continued enzymatic activity and cell dissolution in glutaraldehyde preserved samples.

In one extensive study, Turley \& Hughes (1992) investigated and discussed the possible causes of loss of bacteria in preserved seawater samples. They suggested that cells adhering to the wall of the sample bottle could account for 41 to $48 \%$ of the original bacterial concentration in samples stored for about 11 mo. However, 27 to $51 \%$ of the total loss could not be accounted for. Bacterial DNA and RNA are not preserved by aldehydes (Hayat 1981), and enzymatic breakdown activity may also have a deleterious effect on the nucleotides present in bacienid. Conlinued enzymatic activity in glutaraldehyde and formaldehyde preserved organic matter has been reported in several studies (Fahimi \& Drochmans 1968, Kolb-Bachofen 1977, Synowiecki et al. 1982, Shcpard ct al. 1983)

The purpose of this study was to investigate the various processes that may cause the apparent bacterial cell loss in preserved samples. Therefore, we have introduced a new preservation technique, a protease inhibitor in a solution with glutaraldehyde, in order to inhibit enzymatic breakdown of bacteria to improve the preservation and storage time of bacterial samples.

\section{MATERIAL AND METHODS}

Samples. Open ocean water samples for this investigation were collected in the Sargasso Sea at Stn ' $\mathrm{S}$ ' $\left(32^{\circ} 10^{\prime} \mathrm{N}, 64^{\circ} 30^{\prime} \mathrm{W}\right)$ and at the Bermuda Atlantic Time-series Study (BATS) site $\left(31^{\circ} 50^{\prime} \mathrm{N}, 64^{\circ} 10^{\prime} \mathrm{W}\right)$ at 80 and $100 \mathrm{~m}$ depth. Coastal and estuarine water samples were collected at the surface in Bergen Harbour and from Raunefjorden $20 \mathrm{~km}$ south of Bergen, Norway. We used unbuffered, unfiltered glutaraldehyde (25\% v/v Baker Analyzed Reagent Grade in Bermuda and $25 \% \mathrm{v} / \mathrm{v}$ Merck Electron Microscope Grade in Norway) to preserve the seawater samples.

Bacterial cell counts by transmission electron microscopy (TEM) and EFM. Preparations for the TEM analysis were made by centrifuging algae, bacteria and viral particles in the water sample onto electron microscope grids with carbon stabilized formvar film (Bratbak \& Heldal 1993). Bacteria were counted using a JEOL $100 \mathrm{CX}$ TEM at $20000 \times$ magnification. Similar preparations were used for counting of bacteria containing mature virus particles. For every TEM sample, a minimum of 100 bacterial cells were counted, which results in a counting error of less than $10 \%$ of the calculated mean

For the EFM analysis, $20 \mathrm{ml}$ of open ocean seawater samples and $5 \mathrm{ml}$ of coastal and estuarine water samples were filtered and prepared according to the method of Porter \& Feig (1980). The filtered bacteria were stained using a concentration of $25 \mu \mathrm{g} \mathrm{4}, 6$ diamidino-2-phenylindole (DAPI) per $\mathrm{ml}$ of Milli-Q water Since our time course samples were all closely related in time and distance (Kirchman et al. 1983) only 1 filter per sample per time point was enumerated by the EFM method. An earlier replication study from the Sargasso Sea, using a 2-level nested ANOVA (Sokal \& Rohlf 1969), did not show any significant difference between replicate sample bottles ( $p>0.1$ ), and 76 to $82 \%$ of the variance component was found between the fields counted on a filter ( $K$. Gundersen unpubi. datal.

Loss caused by cell shrinkage and by attachment of cells to the bottle surface. Bacterial samples for the time course experiments were collected at $1 \mathrm{~m}$ depth from Bergen Harbour in January 1993. One sample was preserved with $2.5 \%$ glutaraldehyde and aliquots were distributed into a series of $20 \mathrm{ml}$ polyethylene scintillation vials ( 1 to 3 for each time point). In addition, aliquots of 100 and $1000 \mathrm{ml}$ were stored in glass bottles to check for any effects of volume-to-surface ratio of the sample container All samples were stored at $4^{\circ} \mathrm{C}$ in the dark. Bacteria were enumerated over a time course of $94 \mathrm{~d}$ by the EFM and the TEM methods. On the last day of the experiment, we also counted bacteria in the $100 \mathrm{ml}$ and the $1000 \mathrm{ml}$ samples.

Bacterial adhesion to the inside surface of a sample container, with surface seawater from Raunefjorden, was studied by direct observation using both the EFM and the TEM techniques. The glass sample bottle containing a 1 yr old glutaraldehyde fixed seawater sample was emptied without agitation and the bottle was broken into pieces. Unwashed pieces from the side of the broken bottle were stained with DAPI as described above and mounted in liquid paraffin on a glass slide, with the inside surface facing upwards and with a coverslip on the top. We inspected more than 40 fields of view using EFM, each with an area of $400 \mu^{2}$ at $1000 \times$ magnification. Replicas for TEM of the inside surface of the bottle were made by coating unwashed pieces ( 3 to $6 \mathrm{~mm}^{3}$ ) of the crushed bottle with platinum. and carbon in a Balzers BAF 400 Freezetcher: platinum at $45^{\circ} \mathrm{C}, 1900 \mathrm{~V}, 80 \mathrm{~mA}(2 \mathrm{~nm})$ and carbon at $90^{\circ} \mathrm{C}$, $2400 \mathrm{~V}, 120 \mathrm{~mA}(20 \mathrm{~nm})$. The replicas were transferred to electron microscope grids and inspected in the TEM. More than 200 fields of view, with an area of $50 \mu^{2}$ at $20000 \times$ magnification, were inspected by the TEM 
technique. The inside area of the glass bottle that was covered by the seawater sample was calculated to be $100 \mathrm{~cm}^{2}$.

Disappearance of cells with mature viral particles. During a mesocosm experiment conducted in May 1993 at the Marine Biological Field Station at Raunefjorden, the fraction of bacteria containing mature viral particles varied from $<1 \%$ to about $30 \%$ (Heimdal et al. 1995). In order to check for a loss of bacterial cells, selected samples from these experiments were preserved with $2.5 \%$ glutaraldehyde, stored for $72 \mathrm{~d}$ at $4^{\circ} \mathrm{C}$ and then recounted in the TEM.

Enzyme activity. In a first attempt to inhibit the impact of enzymatic activity on cell lysis and disintegration of bacteria, water was collected from $100 \mathrm{~m}$ depth in November 1992 at Stn ' $S$ ' in the Sargasso Sea, quick frozen in liquid nitrogen and stored at $-20^{\circ} \mathrm{C}$. Over a time course of $43 \mathrm{~d}$, quick frozen samples of natural seawater and seawater preserved in $2.5 \%$ glutaraldehyde, were compared to samples preserved in $2.5 \%$ glutaraldehyde stored at $+4^{\circ} \mathrm{C}$. The frozen samples were thawed in cold tap water and processed immediately. The number of bacteria was counted by the EFM method.

A protease inhibitor, phenylmethylsulfonylfluoride (PMSF; Turini et al. 1969, James 1978, Moss \& Fahrney 1978), was added to bottles containing Sargasso Sea water from $80 \mathrm{~m}$ depth at Stn 'S' in September 1993 and from $80 \mathrm{~m}$ depth at the BATS site in April 1994. PMSF is not readily soluble in aqueous solutions and we found that final concentrations higher than $1 \mu \mathrm{M}$ precipitated out of the seawater Stock solutions of PMSF, stored in pure alcohol, were stable for at least a month (James 1978). A $100 \mu \mathrm{M}$ stock solution of PMSF was prepared fresh in $95 \%$ ethanol a couple of days prior to use. In the September 1993 time course experiment, one series of seawater samples was supplemented with PMSF to a final concentration of $1 \mu \mathrm{M}$. After 5 min at room-temperature, glutaraldehyde was added to a final concentration of $2.5 \%$. Another series of seawater samples was preserved in $2.5 \%$ glutaraldehyde. All the sample bottles were stored at $+4^{\circ} \mathrm{C}$. A time zero sample was filtered, stained with DAPI and prepared immediately from both treatments. All stained preparations were stored at $-20^{\circ} \mathrm{C}$. At the end of the time course, all samples were thawed and enumerated by the EFM method. One sample, designating a single time point, was prepared and counted from each bottle.

In the April 1994 time course experiment, Sargasso Sea water with 2 different concentrations of PMSF $(0.5$ and $1.0 \mu \mathrm{M}$ final conc.) and $2.5 \%$ glutaraldehyde was compared to seawater samples preserved in $2.5 \%$ glutaraldehyde only. The samples were prepared and enumerated by the EFM method.

\section{RESULTS AND DISCUSSION}

\section{Loss of bacteria by filtration and cells adhering to the container's inside surface}

A comparison of the EFM and the TEM techniques (Fig. 1) shows that, with both techniques, the number of bacteria decreased on average by $43 \%$ over the $94 \mathrm{~d}$ time course. The basic difference between these 2 methods is that the preparation for EFM is based on filtration and staining of cellular DNA with the fluorescent dye DAPI, while preparation for TEM is based on centrifugation onto a formvar film and contrast staining of the cells with uralyl acetate. This leads us to conclude that the loss of cells cannot be caused by increased filtrational loss due to cell shrinkage as a function of storage time and that the EFM method of enumerating bacteria worked as well as the TEM method.

Less than $0.6 \%$ of the original number of bacteria from Bergen Harbour $\left(2 \times 10^{9} \mathrm{l}^{-1}\right)$ enumerated by the TEM replica technique was found to be attached to the inside surface of the sample bottle after 1 yr storage time. Corresponding values obtained with DAPI staining and the EFM method were less than $0.4 \%$. Moreover, there was no significant difference $(p>0.05)$ in bacterial numbers in samples stored in bottles with volumes ranging from $20 \mathrm{ml}$ to $1 \mathrm{l}$ (Fig. 1) although the surface-to-volume ratio of these sample containers differed by a factor of 4 .

Turley \& Hughes (1992) were able to recover 37 to $70 \%$ (percentage of initial number of bacteria) by a

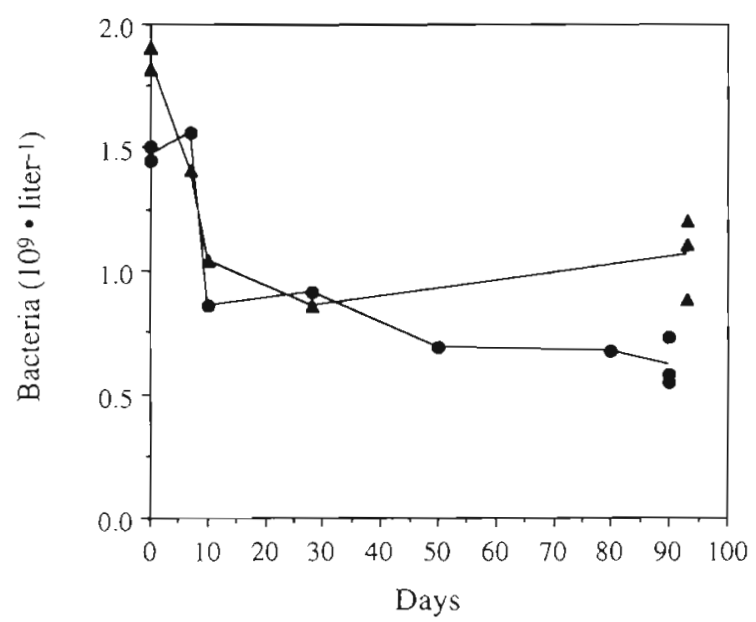

Fig. 1. Bacterial number as a function of storage time in seawater samples preserved with $2.5 \%$ glutaraldehyde (final conc.) from Bergen Harbour in January 1993. The samples were stored in $20 \mathrm{ml}$ scintillation vials. Bacteria were enumerated by the EFM ( $\bullet$ ) and the TEM (A) methods. The triplicates at the end of the time course are bacteria samples stored in 20,100 and $1000 \mathrm{ml}$ glass bottles 
4 min sonication of samples stored for 338 to $340 \mathrm{~d}$. We sonicated 4 wk old glutaraldehyde fixed seawater samples from the Sargasso Sea in an attempt to recover the missing $30 \%$ of the bacteria. We were not able to recover any significant amount of bacteria $(p>0.9)$ after 1 min of sonication prior to counting the samples by epifluorescence microscopy. More than 1 min continuous sonication reduced the number of bacteria ( $\mathrm{K}$. Gundersen unpubl. data). In comparison, Turley \& Hughes (1992) found an increase of 1.5 to 2.5 times the initial cell number after only 1 min sonication of samples stored for 338 to $340 \mathrm{~d}$.

These results suggest that the loss of bacteria in our samples cannot be explained by attachment to the walls of the sample container. Turley \& Hughes (1992) also found that 30 to $90 \%$ of bacteria remained unaccounted for and concluded that other factors as well as attachment must play a significant role in cell loss with time. Although there is a considerable difference in storage time between these 2 sonication studies, the reason for the discrepancy between our observations is not readily explained. Different properties of the bacterial communities used in the experiments may be one possibility, since Turley \& Hughes (1992) used bacteria from the North Atlantic, whereas our collections were from the Sargasso Sea. Wiik (1984) noted that sonicating cultured bacteria longer than 2 min damaged and disrupted the cells. However, Turley \& Hughes (1992) studied the effect of sonication on fresh seawater samples and found that $4 \times 1$ min sonication with cooling and shaking in between resulted in no decrease in bacterial cell numbers (C. Turley pers. comm ). Different surface properties of the sample containers could be another possible explanation, since Turley \& Hughes (1992) used polystyrene tissue culture flasks, whereas we used glass bottles and polyethylene scintillation vials in our study. More recently, however, Turley \& Hughes (1994) found no significant difference in bacterial cell numbers between polystyrene tissue culture flasks and nalgene bottles.

\section{Viral lysis}

The potential loss of cells in preserved samples due to lysis and disintegration of cells in the late stage of the lytic cycle was not supported by our results (Fig. 2). We observed a slightly negative correlation, suggesting that the cell losses were lower in samples where there were more cells in lysis. We only detected bacteria containing mature viral particles. If it had been possible to include cells at any stage in the lytic cycle (i.e. all cells that were bound for lysis at the time the sample was preserved) the results may have been different.

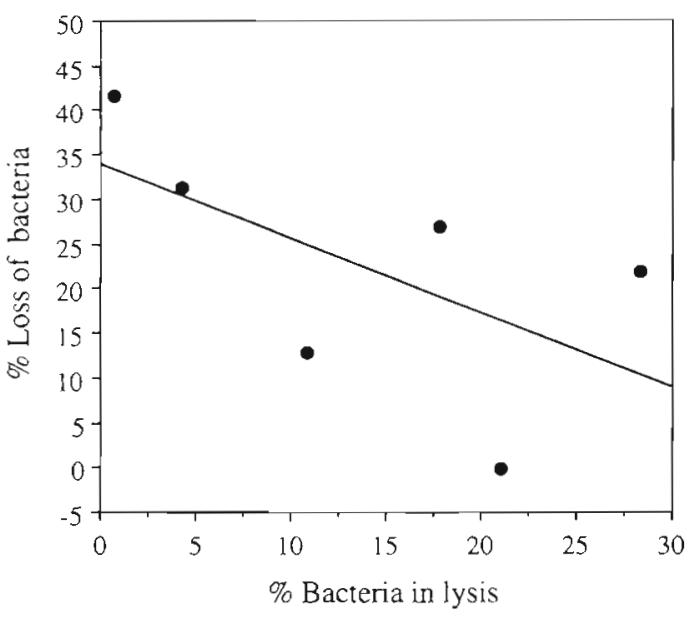

Fig. 2. Loss of bacteria in seawater samples preserved with $2.5 \%$ glutaraldehyde (final concentration) and stored for $72 \mathrm{~d}$ as a function of the percentage of cells containing mature viral particles at the time of sampling $\left(\mathrm{r}^{2}=0.361, \mathrm{p}=0.207\right)$

\section{Enzyme activity}

Bacterial numbers in samples preserved with glutaraldehyde, quick frozen and stored at $-20^{\circ} \mathrm{C}$ declined by only $5 \%$ after $9 \mathrm{~d}$ of storage (Fig. 3). Bacteria in the preserved samples stored at $4^{\circ} \mathrm{C}$ and in the unpreserved frozen samples had at this time point reached 72 and $81 \%$ of the initial concentration. After $16 \mathrm{~d}$ the bacterial numbers were reduced to $56-62 \%$ of the initial concentation in all treatments

By adding 1.0 $\mu \mathrm{M}$ PMSF to Sargasso Sea water samples prior to the addition of $2.5 \%$ glutaraldehyde, we

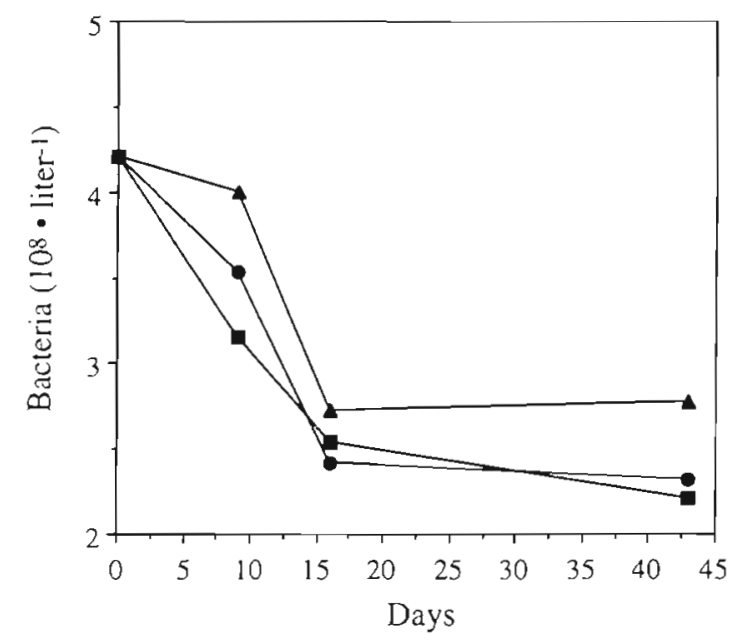

Fig. 3. Bacterial number as a function of storage time in seawater samples taken from $100 \mathrm{~m}$ depth at Stn 'S' in the Sargasso Sea in September 1992. (•) Unpreserved seawater, quick-frozen in Iiquid nitrogen and stored at $-20^{\circ} \mathrm{C}$; (4) seawater preserved in $2.5 \%$ glutaraldehyde (final conc.), quickfrozen in liquid nitrogen and stored at $-20^{\circ} \mathrm{C}$ ( preserved in $2.5 \%$ glutaraldehyde and stored at $+4^{\circ} \mathrm{C}$ 
lost only 17 and $18 \%$ of the bacterial cells after 21 and 36 d of storage time (Fig. 4A, B). During the same time course, bacteria in seawater samples preserved only with glutaraldehyde decreased by 50 and $25 \%$ (Fig. $4 \mathrm{~A}, \mathrm{~B})$. By using 1.0 $\mu \mathrm{M}$ PMSF prior to the addition of glutaraldehyde the loss was only 7 and $13 \%$ of the initial concentration of bacteria in both experiments after 9 and $8 \mathrm{~d}$ (Fig. 4). Although the difference between the treatments was less pronounced in the latter experiment (Fig. 4B), the same trend over time was observed: seawater samples preserved with $1.0 \mu \mathrm{M}$ PMSF and glutaraldehyde had a higher number of bacteria than seawater preserved only with glutaraldehyde (Fig. 4B). In the second time course experiment we used final concentrations of 0.5 and $1.0 \mu \mathrm{M}$ PMSF and we found a positive linear correlation between number of bacterial cells preserved and the concentration of PMSF used after 9 and $21 \mathrm{~d}$ of storage $\left(\mathrm{r}^{2}=0.626, \mathrm{n}=4\right)$.
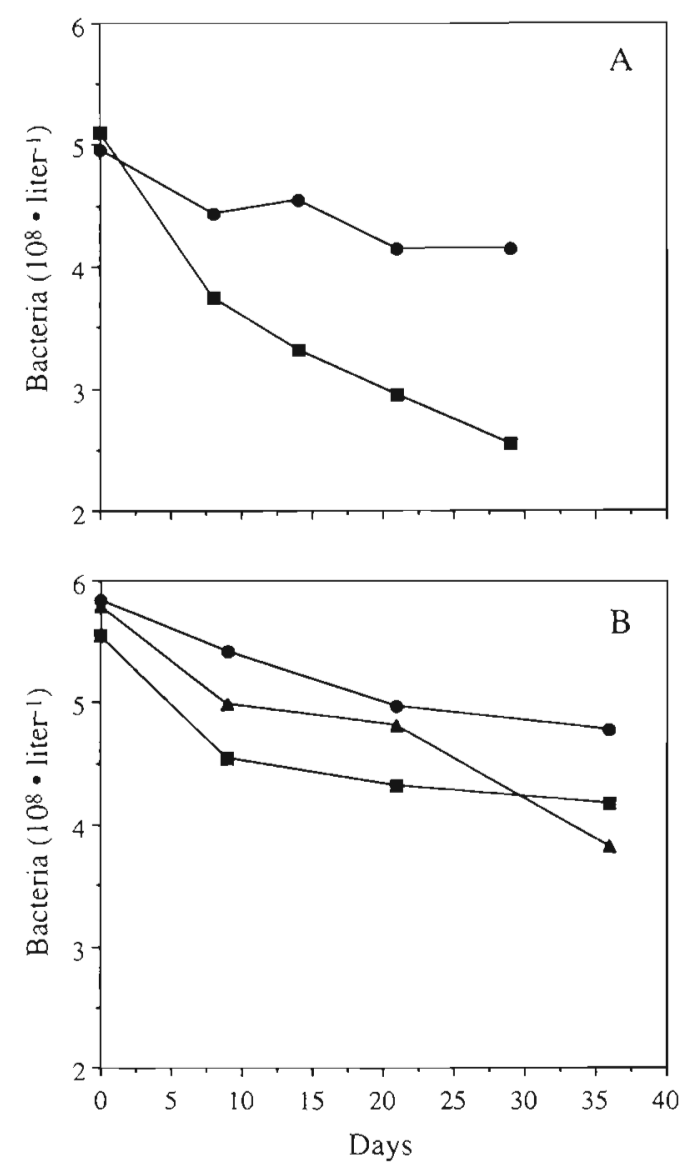

Fig. 4. Bacterial number as a function of storage time in seawater samples taken from $80 \mathrm{~m}$ depth (A) at Stn 'S' in September 1993 and (B) at the BATS station in April 1994. ( Seawater preserved in $1.0 \mu \mathrm{M}$ PMSF and $2.5 \%$ glutaraldehyde (final ronr !: (A) seawater preserved in $0.5 \mu M$ PMSF and $2.5 \%$ glutaraldehyde (ロ seawater preserved in $2.5 \%$ glutaraldehyde. All samples were stored at $+4^{\circ} \mathrm{C}$ during the time course
These results suggest that the loss of bacterial cells can be delayed several days by freezing seawater samples at $-20^{\circ} \mathrm{C}$ and that the addition of a protease inhibitor (PMSF) can slow down the loss significantly. Furthermore, our findings indicate that a considerable part of the loss of bacteria must be related to enzymatic breakdown of cells in the preserved sample. Addition of $2.5 \%$ glutaraldehyde may thus not be sufficient to stop enzymatic activity in the water or in the bacterial cells, leading to cell lysis and disintegration.

PMSF is unstable in aqueous solutions and we found that a precipitate was formed in our seawater samples at concentrations higher than $1 \mu \mathrm{M}$. Thus, other protease inhibitors may be better suited for inhibiting protease activity in preserved seawater. James (1978) found that PMSF inhibited enzymes are not reactivated when the inhibitor is deactivated. We observed a minor reduction of bacterial cells $\left(3 \times 10^{6} \mathrm{l}^{-1} \mathrm{~d}^{-1}\right)$ in samples pretreated with $1 \mu \mathrm{M}$ PMSF (Fig. $4 \mathrm{~A}, \mathrm{~B}$ ). This result may suggest that PMSF insufficiently inhibited the enzymatic breakdown of bacterial cells or that factors other than proteolytic activity are responsible for the loss of bacteria as a function of storage time.

\section{Summary}

Turley \& Hughes (1992) concluded that 41 to $48 \%$ of the original concentration of bacteria was lost due to cells adhering to the wall of the sample containers. In the same study, 27 to $51 \%$ of the observed loss of bacterial cells could not be accounted for (Turley \& Hughes 1992). Our study shows that proteolytic breakdown activity of the cells may be a major cause of the documented losses of bacteria in glutaraldehyde preserved samples. We were able to store frozen seawater samples $\left(-20^{\circ} \mathrm{C}\right)$ preserved in glutaraldehyde, and seawater samples treated with a protease inhibitor such as PMSF prior to the glutaraldehyde addition, for as long as 1 wk without any major loss of bacterial cells. Nevertheless, we support the recommendation made by Turley \& Hughes (1992) that bacteria samples should be preserved, stained, filtered and mounted on slides as soon after sampling as possible and then stored frozen $\left(-20^{\circ} \mathrm{C}\right)$ until enumerated.

Acknowledgements. We thank K. M. Orcutt and $\varnothing$. Enger, for exposure to the use of PMSF in seawater samples. K.G. acknowledges the support of A. H. Knap, A. F. Michaels (OCE-8801089, OCE-9301950) and the BATS technicians at BBSR. A. R. Close helped with counting bacteria in the sonication experiment. J. Gallon provided crucial information about the PMST. The election milioscupe wolk was done at the Laboratory for Electron Microscopy, University of Bergen, Norway. N. R. Bates, C. Turley and 1 anonymous reviewer made helpful comments on the manuscript. This is BBSR con- 
tribution number 1428 . The work was supported by funding from The Research Council of Norway to the MAST-II project MEICE (G.B. and M.H.), contract number MAS2-CT92-0031.

\section{LITERATURE CITED}

Azam $F$, Fenchel T. Field JG, Gray JS, Meyer-Rell LA, Thingstar $F(1983)$ The ecological role of water-column microbes in the sea. Mar Ecol Prog Ser 10:257-263

Bratbak G. Heldal M (1993) Total count of viruses in aquatic environments. In: Kelp PF, Sherr BF, Sherr EB, Cole JJ (eds) Current methods in aquatic microbial ecology. Lewis Publishers, London, p 135-138

Caron DA, Dam IIG, Kremer P, Lessard EJ, Madin LP, Malone TC, Napp JM, Peele ER, Roman MR, Youngbluth MJ (1995) The contribution of microorganisms to particulate carbon and nitrogen in surface waters of the Sargasso Sea near Bermuda. Deep Sea Res 42:943-972

Cho BC, Azam F (1990) Biogeochemical significance of bacterial biomass in the ocean's euphotic zone. Mar Ecol Prog Ser 63:253-259

Dortch Q. Packard TI (1989) Diffenences in biomass structure between oligotrophic and eutrophic marine ecosystems. Deep Sea Res 36:223-240

Fahımi HD, Drochmans P (1968) Purification of glutaraldehyde its significance for preservation of acid phosphatase activity. J Hisluchem Cytochem 16.199-204

Fuhrman JA, Sleeter TD, Carlson CA, Proctor LM (1989) Dominance of bacterial bromass in the Sargasso Sea and its ecological implications. Mar Ecol Prog Ser 57:207-217

Hayat MA (1981) Fixation for electron microscopy. Academic Press, New York

Heimdal BR, Egge JK, Veldhuis MJW, Westbroek P (1994) Introduction to the 1992 Norwegian EHUX experiment. Sarsia 79:285-290

Hobbie JE, Daley RJ, Jasper S (1977) Use of Nucleopore filters for counting barteria by fluorescence microscopy. Appl Environ Microbiol 33:1225-1228

James GT (1978) Inactivation of the protease inhibitor Phenylmethylsulfonyl Fluoride in buffers. Analyt Biochem 86: $574-579$

Kirchman D, Sigda J, Kapuscinski. R, Mitchell R (1983) Statistical analysis of the direct count method for enumerating bacteria. Appl Environ Microbiol 44:376-382

Kolb-Bachofen $\vee(1977)$ Electron microscopic localization of acıd phosphatase in Tetrahymena pyriformis: the influence of activities of lysosomal enzymes on fixation and structural preservation. Cytobiologie 15:135-144

This article was presented by B. \& E. Sherr (Senior Editonal Advisors), Corvallis, Oregon, LSA
Li WK, Dickie PM, Irwin BD, Wood AM (1992) Biomass of bacteria, cyanobacteria, prochlorophytes and photosynthetic eucaryotes in the Sargasso Sea. Deep Sea Res 39:501-519

Moss DE, Fahrney D (1978) Kinetic analysis of differences in brain acetylcholinesterase from ish or mammalian sources. Biochem Pharmacol 27:2693-2698

Nishino SF (1986) Direct acridine orange counting of bacteria preserved with acidified Lugol 1odine. Appl Environ Microbiol 52:602-604

Pomeroy LR (1974) The ocean's food web, a changing paradigm. BioScience 24:499-504

Porter KG, Feig YS (1980) The use of DAPI for identifying and counting aquatic microflora. Limnol Oceanogr 25:943-948

Roman MR, Caron DA, Kremer P, Lessard EJ, Madin LP, Malone TC, Napp JM, Peele ER, Youngbluth MJ (1995) Spatial and temporal changes in the partitioning of organic carbon in the plankton community of the Sargasso Sea off Bermuda. Deep Sea Res 42:973-992

Shepard D, Donovan $M$, Raghupathy $E$, Yeung $K K$, Dain JA (1983) Effect of immobilization on the stability and substrate specificity of alpha-D-galactosidase isolated from the invertebrate Turbo cornutus. Carbohydrate Res 118 : $239-245$

Sokal RR, Rohlf FJ (1969) Biometry. WH Freeman \& Co, New York

Spinrad RW, Glover H, Ward BB, Codispoti LA, Kullenberg G (1989) Suspended particle and bacterial maxima in Peruvian coastal waters during a cold water anomaly. Deep Sea Res 36:715-733

Synowiecki J, Sikorski ZE, Naczk M, Piotrzkowska H (1982) Immobilization of enzymes on krill chitin activated by formaldehyde. Biotechnol Bioeng 24:1871-1876

Turini P, Kurooka S, Steer M, Corbascio AN, Singer TP (1969) The action of Phenylmethylsulfonyl Fluoride on human acetylcholinesterase, chymotrypsin and trypsin. J Pharmacol Exp Ther 167:98-104

Turley C, Hughes DJ (1992) Effects of storage on direct estimates of bacterial numbers of preserved seawater samples. Deep Sea Res 39:375-394

Turley C, Hughes DJ (1994) The effect of storage temperature on the enumeration of epifluorescence-detectable bacterial cells in preserved sea-water samples. J Mar Biol Ass UK 74:259-262

Wiik R (1984) Aerococcus viradians var. homari i norsk hummer? Påvisning og genetisk karakterısering av bakterien. MSc thesis, University of Bergen

Zimmerman R, Meyer-Reil LA (1974) A new method for fluorescence staining of bacterial populations on membrane filters. Kieler Meeresforsch 31:24-27

Manuscript first recelved: January 20,1995

Revised version accepted: January 9, 1996 


\title{
NOTE
}

\section{Impact of iceberg scouring on polar benthic habitats}

\author{
Julian Gutt*, Andreas Starmans, Gerhard Dieckmann
}

Alfred Wegener Institute for Polar and Marine Research, Columbusstraße, D-27568 Bremerhaven, Germany

\begin{abstract}
In situ photographs and videos demonstrate that iceberg grounding in both polar regions causes considerable damage to benthic communities. Sessile organisms are eradicated and pioneer species begin to grow in high abundances on the devastated substratum. A preliminary quantitative analysis shows that the sea floor in the Antarctic and Arctic areas of investigation is disturbed by icebergs statistically once every 230 and $53 \mathrm{yr}$, respectively. Due to the extreme slow growth of many species, particularly in Antarctica, areas frequently disturbed in this manner are likely to be characterised by a continuous natural fluctuation between destruction and recovery. Increased perturbation by iceberg groundings through predicted global warming will result in considerable impairment of this environment.
\end{abstract}

KEY WORDS: Antarctic Arctic Benthos I Iceberg scouring Global warming

Recently, the calving of Antarctic ice shelves has been discussed with respect to global warming (Doake \& Vaughan 1991, Gammie 1995) and the consequences of resulting iceberg scouring on the structure of the sea bed have been documented for both polar areas (Lien et al. 1989, Woodworth-Lynas et al. 1991). Yet the possible effect on the underlying benthic communities, other than by small growlers, has not yet been broached. Our analysis shows for the first time the impact of iceberg grounding and scouring on the Antarctic and Arctic benthos. The results provide an idea of the benthic system's resilience to such natural catastrophic events. They also enable us to assess consequences of a possible atmospheric warming, to which both polar ecosystems are considered particularly sensitive (Houghton et al. 1990).

Material and methods. The sea floor was videotaped by a remotely operated vehicle and photographed in the Antarctic Weddell and Lazarev Seas $\left(47^{\circ} \mathrm{W}\right.$ to $12^{\circ} \mathrm{E}, 69^{\circ} \mathrm{S}$ to $\left.79^{\circ} \mathrm{S}\right)$ and the Amundsen and Bellingshausen Seas $\left(120^{\circ} \mathrm{W}\right.$ to $65^{\circ} \mathrm{W}, 67^{\circ} \mathrm{S}$ to $73^{\circ} \mathrm{S}$; Fig. 1a) as well as off northeast Greenland $\left(77^{\circ} \mathrm{N}\right.$ to
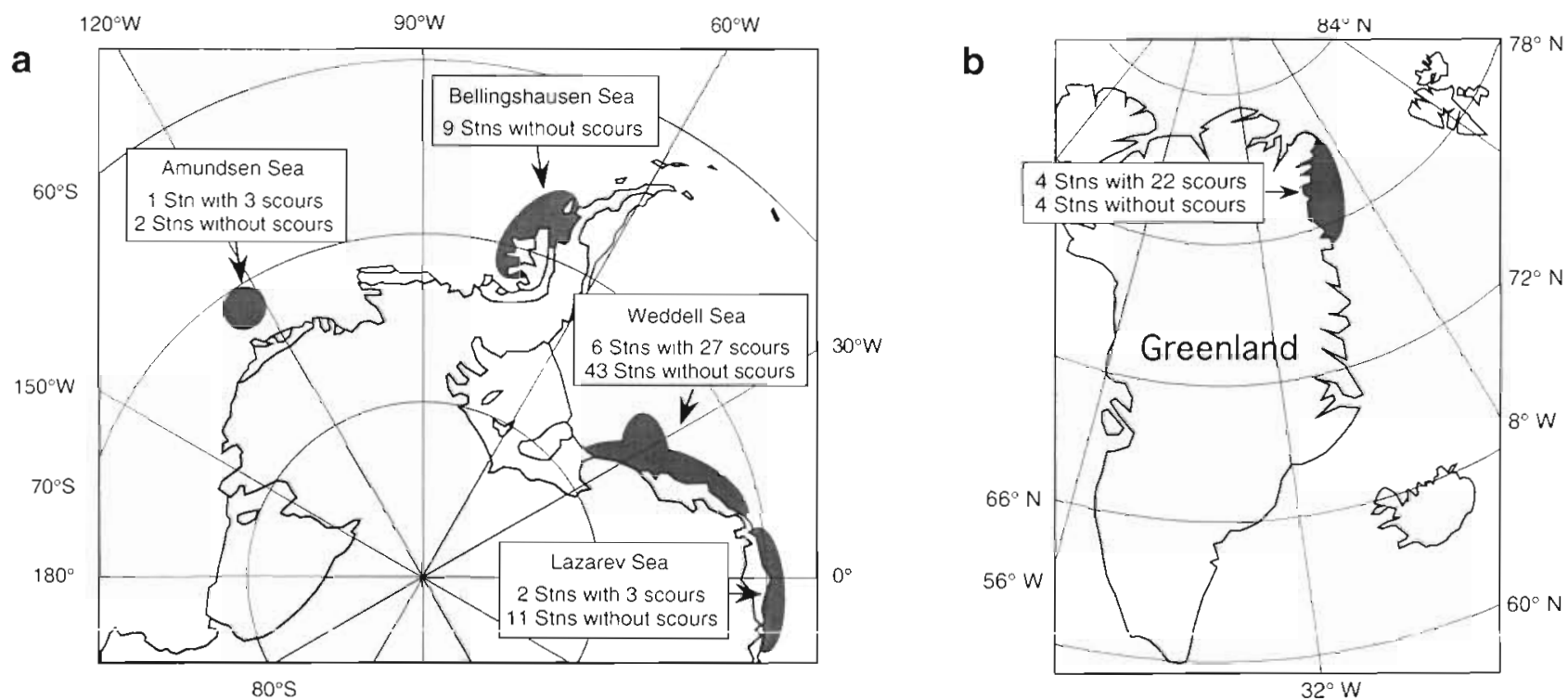

Fig. 1. Areas of investigation: (a) Antarctic, (b) off northeast Greenland

-E-mail: jgutt@awi-bremerhaven.de 